\title{
Angka Kuman Pada Alat Makan di Kantin SDN No.47 Telanaipura Kota Jambi
}

\author{
Supriadi, Emilia Chandra \\ Poltekkes Kemenkes Jambi \\ Email: yadisupriadi64@yahoo.co.id
}

\begin{abstract}
Common environmental-based diseases are often a problem of diarrhea, ARl, and hepatitis caused by an unhealthy environment, including in the canteen environment of the 47 Telanaipura Jambi Primary School. This study aims to determine the Germ Number in eating utensils and how to wash eating utensils in the cafeteria of SDN 47 Telanaipura, Jambi City. This research method uses descriptive design, namely research carried out to describe a situation without giving treatment to the object that aims to study canteen sanitation and the number of germs on eating utensils in the cafeteria SDN No. 47 Jambi City. Analyzing data uni variat and presented in table form then analyzed descriptively and laboratory tests. The results of the research on Germination Figures in Eating Appliances in the SDN 47 Canteen obtained 40\% more than the permissible germination rate of 100 colonies / $\mathrm{cm}^{2}$ and Washing of food in SDN 47 Telanaipura Jambi had used the recommended washing technique using flowing water. It is suggested that the canteen sword does not use plastic plates, paying attention to the means of storing cutlery and the school is expected to facilitate the provision of closed storage cabinets.
\end{abstract}

Keywords: germ numbers, cutlery, Canteen SDN 47 Telanaipura Jambi

\section{PENDAHULUAN}

Makanan merupakan kebutuhan mendasar bagi hidup manusia. Makanan yang dikonsumsi beragam jenis dengan berbagai cara pengolahannya (Santoso, 1999). Makanan-makanan tersebut sangat mungkin sekali menjadi penyebab terjadinya gangguan dalam tubuh kita sehingga kita jatuh sakit. Salah satu cara untuk memelihara kesehatan adalah dengan mengkonsumsi makanan yang aman, yaitu dengan memastikan bahwa makanan tersebut dalam keadaan bersih dan terhindar dari wholesomeness (penyakit), hal yang dapat menyebabkan suatu makanan menjadi tidak aman, salah satu diantaranya dikarenakan terkontaminasi (Thaheer, 2005).

Kontaminasi yang terjadi pada makanan dan minuman dapat menyebabkan makanan tersebut dapat menjadi media bagi suatu penyakit. Penyakit yang ditimbulkan oleh makanan yang terkontaminasi disebut penyakit bawaan makanan (food-borned diseases) (Susanna, 2003).

Keberadaan kantin sangat penting untuk menyediakan makanan dan minuman bagi anak sekolah. Kantin Sekolah Dasar (SD) harus mendapatkan perhatian dari berbagai pihak, karena anak-anak merupakan kelompok yang berisiko tinggi tertular penyakit melalui makanan maupun minuman (Antara, 2004). Anak-anak sering menjadi korban penyakit bawaan makanan akibat konsumsi makanan yang disiapkan di rumah sendiri atau di kantin sekolah atau yang dibeli di penjaja kaki lima (World Health Organization [WHO], 2006).

Kantin sekolah merupakan tempat umum, dimana tempat-tempat umum merupakan tempat menyebarnya segala macam penyakit baik melalui makanan, minuman. Air dan udara maupun peralatan makanan (Mukona, 2000). Setiap kantin memiliki petugas yang menangani alat makan, petugas yang menangani alat makan mempunyai kapasitas dalam menentukan keamanan makanan yang ada di kantin sekolah untuk terhindar dari gangguan kesehatan, maka diperlukan sarana pencucian alat makan. Cara pencucian alat makan dan cara penyimpanan alat makan dikantin Sekolah Dasar.
Menurut Fardiaz (1997), terkontaminasinya makanan terutama disebabkan oleh berbagai faktor antara lain pengetahuan petugas atau orang yang menangani makanan masih rendah termasuk perilaku kesehatan, personal hygiene, kebersihan alat makan dan sanitasi makanan.

Penelitian Djaja (2003) di 3 (tiga) jenis tempat pengelolaan makanan (TPM) menyimpulkan bahwa pedagang kaki lima berisiko 3,5 kali lipat terhadap terjadinya kontaminasi makanan dibandingkan dengan usaha jasaboga, restoran dan rumah makan. Kontaminasi makanan pada pedagang kaki lima dapat terjadi karena sanitasi dapur pengolahan makanan dan tempat penyajian makanan mungkin belum memenuhi persyaratan kesehatan.

Menurut Tamaroh (2002) dalam Zulkifli (2008) beberapa faktor yang menentukan keamanan makanan di antaranya jenis makanan olahan, cara penanganan bahan makanan, cara penyajian, waktu antara makanan matang dikonsumsi dan suhu penyimpanan baik pada bahan makanan mentah maupun makanan matang dan perilaku penjamah makanan itu sendiri.

Menurut Kusmayadi (2007) terdapat 4 (empat) hal penting prinsip higiene dan sanitasi makanan meliputi perilaku sehat dan bersih orang yang mengelola makanan, sanitasi makanan, sanitasi peralatan dan sanitasi tempat pengolahan Makanan dapat terkontaminasi mikroba karena beberapa hal, seperti menggunakan lap kotor untuk membersihkan meja, perabotan bersih dan lainnya serta makanan disimpan tanpa tutup sehingga serangga dan tikus dapat menjangkaunya serta pengolah makanan yang sakit atau karier penyakit (Slamet, 1994).

Penyakit bawaan makanan merupakan salah satu permasalahan kesehatan masyarakat yang paling banyak dan paling membebani yang pernah dijumpai di zaman modern ini. Penyakit tersebut menimbulkan banyak korban dalam kehidupan manusia dan menyebabkan sejumlah besar penderitaan, khususnya di kalangan bayi, anak, lansia dan mereka yang kekebalan tubuhnya terganggu (WHO, 2006).

Sejumlah survei terhadap kejadian luar biasa (KLB) penyakit bawaan makanan yang berjangkit di 
seluruh dunia memperlihatkan bahwa sebagian besar kasus penyakit bawaan makanan terjadi akibat kesalahan penanganan pada saat penyiapan makanan tersebut baik di rumah, jasa katering, kantin rumah sakit, sekolah atau di pangkalan militer atau pada saat jamuan makan atau pesta (WHO, 2006).

Berdasarkan Keputusan Menteri Kesehatan Republik Indonesia Nomor 942/Menkes/SK/VII/2003 tentang Pedoman Persyaratan Hygiene Sanitasi Makanan Jajanan, terdapat beberapa aspek yang diatur dalam penanganan makanan jajanan, yaitu penjamah makanan, peralatan, air, bahan makanan, bahan tambahan makanan, penyajian dan sarana penjaja dan sangat mempengaruhi kualitas makanan.

Berdasarkan Permenkes No. 304 pasal 9 ayat 1 dijelaskan bahwa peralatan yang digunakan harus memenuhi syarat kesehatan. Kebersihan peralatan makanan yang kurang baik akan mempunyai peranan penting dalam pertumbuhan dan perkembangbiakan kuman, penyebaran penyakit dan keracunan, untuk itu peralatan makanan haruslah dijaga terus tingkat kebersihannya supaya terhindar dari kontaminasi kuman patogen serta cemaran zat lainnya.

Kontaminasi pada makanan jadi dapat terjadi apabila makanan yang sudah dimasak bersentuhan dengan peralatan yang sudah terkontaminasi dan diperlakukan dengan tidak higienis. Untuk itu diperlukan pencucian peralatan makan, pencucian secara baik akan menghasilkan peralatan yang bersih dan sehat pula (Depkes RI, 2003). Menurut Permenkes RI No.1096/MENKES/PER/ VI/2011 bahwa untuk mengetahui tingkat kebersihan suatu peralatan makan, dapat dilakukan pemeriksaan bakteriologis dengan indikator angka kuman

Penerapan Full day di Sekolah Dasar merupakan suatu perubahan besar yang berdampak positif maupun negatif, negatifnya adalah siswa full disekolah sekolah, dijelaskannya bahwa siswa kelas I sampai dengan kelas III belajar mulai pukul 07.00 sampai dengan 12.15 . Sedangkan siswa kelas IV sampai dengan kelas VI belajar mulai pukul 07.00 sampai dengan pukul 14.10, jam disekolah juga berpengaruh terhadap kebiasaan jajan dikantin, biasanya siswa dikantin hanya untuk membeli jajanan dan makanan ringan seperti kue dan minuman, namun bila diterapkan fullday maka bergeser membeli makanan berat atau makanan yang mengenyangkan untuk makan siang seperti lontong, soto, mie, nasi dan lainnya. Peneliti mengkhawatirkan kejadian 5 tahun yang lalu terjadi dimana SD 47 merupakan salah satu sekolah yang KLB Hepatitis yang disebabkan oleh kurangnya sanitasi kantin.

Berdasarkan pengamatan awal pada pedagang kantin di SDN 47 Kota Jambi. Pada jam istirahat siswa, petugas kantin disibukkan dengan melayani siswa yang makan di kantin, piring yang digunakan sudah disediakan menumpuk di etalase. Piring di cuci pada sore hari setelah sekolah bubar dan kemudian dipakai lagi keesokan nya untuk alat makan.

Menurut Departemen Kesehatan (Depkes), (1991), kebersihan alat makan ditentukan dengan angka kuman 100 coloni $/ \mathrm{cm}^{2}$ permukaan dan tidak ada kuman E.coli dan data keracunan makanan dari balai POM jambi dari tahun 2005-2008 terdapat 170 kasus keracunan makanan, dimana beberapa kasus tersebut ada kaitannya dengan keracunan oleh mikrobiologi. Salah satu nya penyakti hepatitis.

Penyakit hepatitis menyerang SD 47 Kota Jambi pada tahun 2012. Sedikitnya 15 murid dan 2 guru olahraga terinfeksi radang hati. Sumber penyakit tersebut berasal adanya petugas kantin yang terinfeksi Hepatitis dan menularkan penyakitnya melalui alat makan yang tidak dicuci dengan baik. Tujuan penelitian adalah: 1) Mengetahui bagaimana Angka kuman pada alat makan di kantin SDN No. 47 Telanaipura Kota Jambi; 2) Mengetahui pncucian alat makan di kantin SDN No. 47 Telanaipura Kota Jambi

\section{METODE PENELITIAN Metode}

Metode penelitian yang digunakan dalam penelitian ini meliputi beberapa tahap yaitu pengumpulan data, kemudian di olah secara manual dengan tahap-tahap editing, tabulasi, uji labor dan kemudian dilakukan analisis secara deskriptif dengan membandingkan dengan peraturan yang ada.

\section{Rancangan Penelitian}

Jenis penelitian ini adalah penelitian observasional yang bersifat deskriptif, yaitu penelitian dilakukan untuk menggambarkan suatu keadaan tanpa memberi perlakuan terhadap objek yang bertujuan untuk mempelajari sanitasi kantin serta angka kuman pada alat makan di kantin SDN No. 47 Kota Jambi, jumlah populasi dalam penelitian ini adalah 15 kantin sekolah Dasar, dan sampel yang diambil adalah piring pada kantin yang menggunakan alat makan berupa piring di kantin Sekolah Dasar. Pengambilan data dilakukan dengan menggunakan observasi, cheklist, dan uji laboratorium mengenai angka kuman alat makan. Analisis data dilakukan secara deskriptif dengan melihat hasil labor di sandingkan dengan proses pencucian dan penyimpanan alat makan di kantin.

\section{Desain Penelitian}

Penelitian ini dilakukan dengan disain penelitian deskriptif yaitu menjawab atas pertanyaan-pertanyaan tentang siapa, apa, kapan, di mana dan bagaimana keterkaitan dengan penelitian tertentu. Penelitian deskriptif digunakan untuk memperoleh informasi mengenai status fenomena variabel atau kondisi situasi dan uji laboratorium untuk mengetahui angka kuman.

\section{Perubahan yang di amati/diukur}

Mengamati Mengukur pengetahuan tentang pencucian alat makan dan angka kuman pada alat makan di kantin SDN No. 47 Kota Jambi

\section{Lokasi penelitian}

Tempat penelitian dilakukan di Kantin SDN No. 47 Telanai Pura Kota Jambi pada bulan Mei sampai dengan Oktober 2017

\section{Populasi dan Sampel}

Jumlah populasi dalam penelitian ini adalah 15 kantin sekolah Dasar, dan sampel yang diambil adalah 4 kantin Sekolah Dasar yang menggunakan piring sebagai alat makannya, yang menjadi alasan hanya sampel piring yang diambil karena piring memiliki permukaan 
yang luas dan mudah dibersihkan, piring merupakan indikator bagi peneliti, bila piring saja sudah memiliki angka kuman yang melebihi syarat berarti sendok gelas dan garpu berkemungkinan besar memiliki angka kuman yang lebih besar.

\section{Teknik Penarikan Sampel}

Pengambilan sampel dilakukan dengan total sampling yang menggunakan piring sebagai alat makan.

\section{Teknik Pengumpulan data}

Pengumpulan data dilaksanakan dengan

beberapa tahap yaitu ;

1. Melakukan wawancara dengan menggunakan kuesioner

2. Peneliti memberikan pelatihan terhadap surveyor agar memiliki pemahaman yang sama dengan peneliti dalam pelaksanaan Kegiatan ini.

3. Pengambilan sampel

\section{Analisis Data}

Data yang diperoleh disajikan dalam bentuk tabel distribusi frekuensi kemudian dibandingkan dengan teori yang ada

\section{HASIL DAN PEMBAHASAN \\ Gambaran dan Lokasi Penelitian}

SDN no. 47 Terdiri dari 1.177 siswa, 109 Guru dan 7 Staf, terdiri dari 41 Kelas, 42 pelajaran dan 3 Ekstrakulikuler, berdiri pada tahun 1972, yang terletak di JL. RE Martadinata Telanaipura Jambi, tahun 2017 ini SDN No. 47 berusia 45 tahun. SDN No. 47 ditetapkan oleh Dirjen Diknasmen melalui SK Dirjen Diknasmen Depdiknas No. 448a/C.C2/kep/DS/2003 sebagai salah satu sekolah koalisi nasional bersama 31 sekolah dasar se Indonesia. Pada tanggal 6 April 2005, SDN No. 47 sebagai koalisi nasional diresmikan oleh bapak Walikota Jambi. Tanggal 11 September 2017 SDN No. 47 sebagai Rintisan Sekolah Bertaraf Internasional (RSBI), tanggal 13 Januari 2010 SDN 47 berhasil memperolehSertifikat Sistem Manajemen ISO 9001:2008 dari Tuv Nord Indonesia, Tuv Nord Group. Pada tanggal 15 Juni 2015 SDN 47 ditetapkan sebagai sekolah dasar pembina yang merupakan salah satu program Direktorat pembinaan sekolah dasar dan menengah. Berikut data SDN 47 Kota Jambi

$\begin{array}{ll}\text { NPSN } & 10504908 \\ \text { NSS } & 101100401005 \\ \text { Nama } & \text { SDN 047/IV JAMBI } \\ \text { Akreditasi } & \text { Akreditasi A } \\ \text { Alamat } & \text { JL. RE MARTADINATA } \\ \text { Kodepos } & 123456 \\ \text { Nomer Telpon } & 65544 \\ \text { Nomer Faks } & - \\ \text { Email } & \text { sdn47_jambi@yahoo.com } \\ \text { Jenjang } & \text { SD } \\ \text { Status } & \text { Negeri } \\ \text { Situs } & \text { sdn47.kotajambi.jbisch.net } \\ \text { Lintang } & -1.6043435647188569 \\ \text { Bujur } & 103.63677978515625 \\ \text { Ketinggian } & 21 \\ \text { Waktu Belajar } & \text { Sekolah Pagi dan Sore }\end{array}$

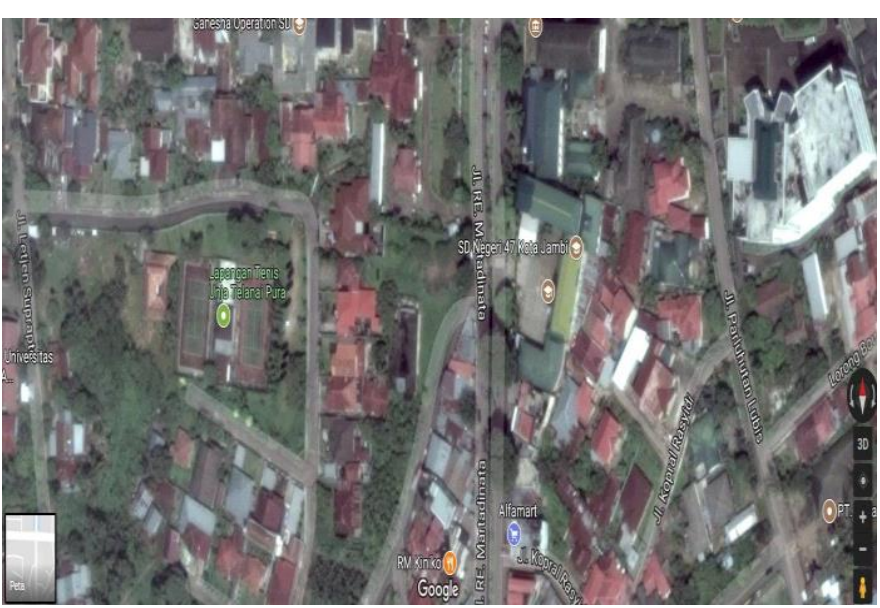

Gambar 1. Peta wilayah lingkungan SDN47 Kota Jambi

\section{Gambaran Kantin SDN 47}

Kantin SDN 47 terletak di bagian belakang kelas, terdiri dari 15 kantin dalam saru lingkungan yang berada dalam lingkungan sekolah, kantin tersebut menjual berbagai jajanan sekolah mulai dari jajanan kemasan, jajanan yang diolah, makanan ringan hingga makanan berat, 15 pedagang tersebut terdiri dari:

Tabel 1. Tabel Jenis Jajanan

\begin{tabular}{lll}
\hline No & Nama Pemilik Kantin & \multicolumn{1}{c}{ Jenis Jajanan } \\
\hline 1 & A & Mie \\
2 & B & Nasi Campur \\
3 & C & Nasi Gemuk \\
4 & D & Minuman \\
5 & E & Soto \\
6 & F & Sosis, Nuget, Cilok, Roti Bakar \\
7 & G & Pisang Keju, Burger, Pizza, Pangsit \\
8 & H & Pempek \\
9 & I & Bakso Bakar, Bakso kuah, Bakso \\
& & Krispi \\
10 & J & Pop Ice \\
11 & K & Es Jagung, Milk Kuat Beku \\
12 & Catur & Ciki dan Permen \\
13 & Ita & Jajanan kemasan, Alat Tulis \\
14 & Makwo & Pisang Krispi, Telor Dada \\
15 & Bude & Mainan, Alat Tulis \\
\hline
\end{tabular}
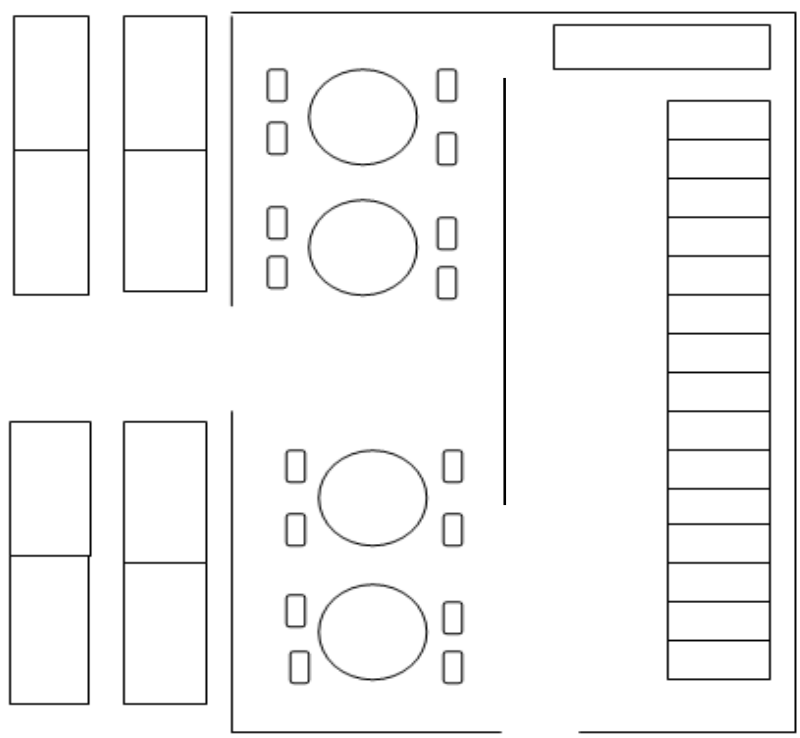

Gambar 2. Gambaran Kantin SDN 47 Kota Jambi 


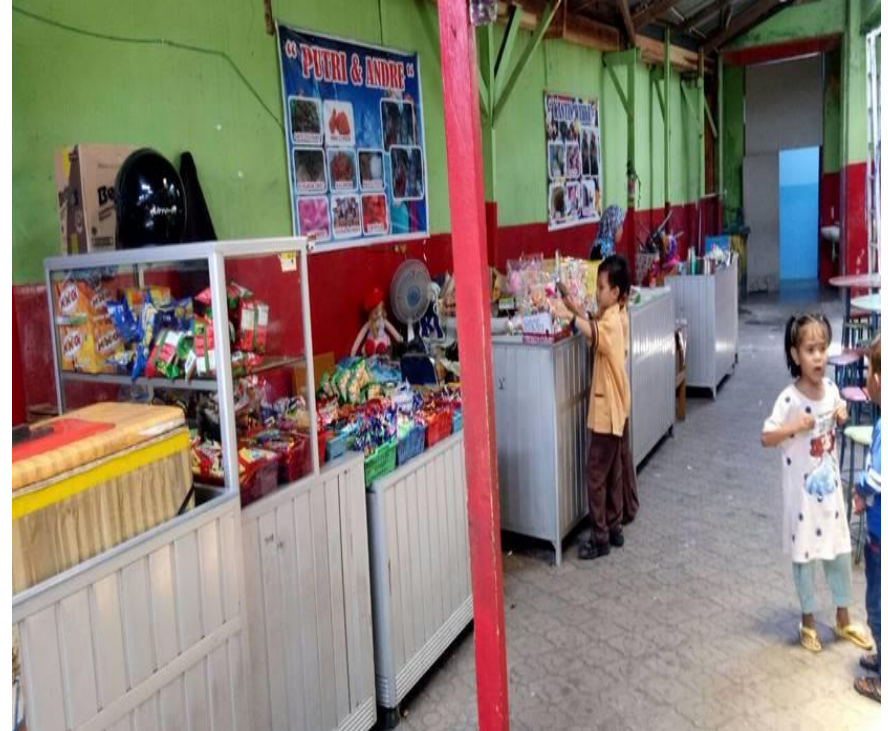

Gambar 3. Kantin SDN 47 Kota Jambi

Dari 15 kantin yang berjualan terdapat 4 kantin yang memakai alat makan selebihnya hanya menggunakan kemasan dan plastik sekali pakai. Dari 4 kantin tersebut masing-masing menyediakan piring sebanyak 50 buah setiap harinya, dan dicuci sekali dalam sehari pada saat anak-anak pulang sekolah, piring dicuci dengan menggunakan air mengalir yang bersumber dari PDAM. Piring yang telah dicuci disimpan pada tempat penyimpanan piring. Untuk kantin $A, C$ dan $D$ piring hanya ditelungkupkan di etalase yang tidak tertutup sedangkan kantin B meletakkan piring kedalam lemari yang tertutup berikut :

Hasil yang diperoleh dari penelitian ini sebagai

\section{Sarana Pencucian}

a. Pencucian menggunakan air kran yang mengalir, air yang digunakan berasal dari air PDAM dan bila air PDAM sedang tidak mengalir, pedagang menggunakan air sumur yang dialirkan menggunakan pipa ke tempat cuci piring

b. peralatan makan terbuat dari bahan yang kuat, aman, tidak berkarat dan mudah dibersihkan namun ada 1 orang pedagang yang menggunakan piring plastik, hal ini dilakukan dengan alasan bila menggunakan piring beling, piring tersebut sering pecah oleh anak-anak SD.

c. Sarana Pencucian peralatan makan terdiri dari 3 bilik/ bak pencucian, Sarana pencucian terdiri dari 2 bak, namun pedagang lebih sering menggunakan satu bak untuk meletakkan piring kotor dan satu bak untuk piring yang sudah dicuci, air yang digunakan untuk mencuci adalah air yang mengalir

d. Sarana pencucian di peralatan makan dilengkapi dengan pembuangan air

e. Sarana pencucian dilengkapi dengan sarana pembuangan air limbah yang di alirkan melalui saluran got.

f. Sarana pencucian di peralatan makan dilengkapi dengan alat penggosok

g. Alat penggosok peralatan makan dipisahkan dengan alat penggosok peralatan masak h. Sarana pencucian peralatan makanan dilengkapi dengan deterjen

i. Sarana pencucian peralatan makanan dilengkapi dengan air mengalir

j. Tidak Tersedia Bahan desinfektan atau air panas

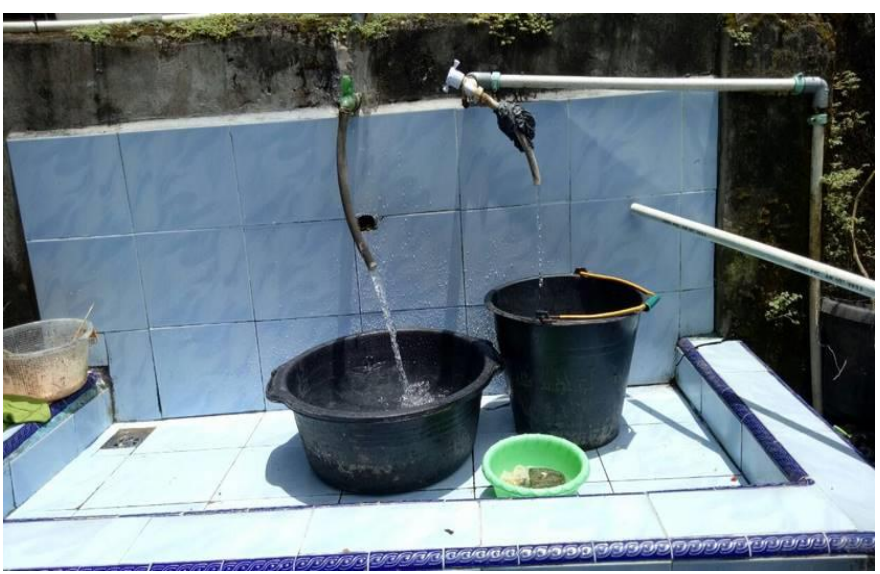

Gambar 4. Sarana Pencucian

\section{Cara pencucian alat makan}

a. Sisa makanan dipisahkan dari Peralatan makan sebelum dilaksanakan pencucian

b. Dilakukan perendaman terlebih dahulu terhadap peralatan makanan sebelum dilaksanakan proses pencucian

c. Dilakukan pencucian dengan menggunakan deterjen terhadap peralatan makanan yang kotor

d. Di dalam pencucian peralatan makan diakukan dengan penggosokan berulang kali

e. Setelah penyabunan/ penggosokan peralatan makan dilakukan pembilasan dengan air yang mengalir/bertekanan

f. Peralatan makan yang telah dibilas tidak direndam dengan air panas atau desinfektan lainnya ( kaporit)

g. Peralatan makan yang tela dibilas diletakkan pada tempat penirisan dengan cara dimiringkan /terbalik

h. Didalam melakukan pengeringan peralatan makan tidak menggunakan lap sekali pakai atau tissue

\section{Tempat Penyimpanan Peralatan Makan}

a. Temat Penyimpanan Peralatan Makanan terbuat dari dari bahan yang kuat, aman. dan tidak berkarat

b. Tempat penyimpanan untuk pedagang $B$ terlindung atau aman dari pencemaran (debu, serangga atau tikus), pedagang lain tidak memenuhi syarat ini.

c. Tempat penympanan peralatan makan letaknya tidak terlalu jauh dari tempat pencucian peralatan makan

d. Tempat penyimpanan peralatan mudah dibersihkan

e. Tempat penyimpanan peralatan dalam keadaan baik (tidak bocor,rusak, atau terbuka)

f. Tempat peralatan makan terlihat bersih

g. Tempat penyimpan peralatan makan mudah dijangkau sewaktu diperluakan 
h. Penyimpanan peralatan makan tidak bersama dengan penyimpanan peralatan masak dan bahan makanan lainnya

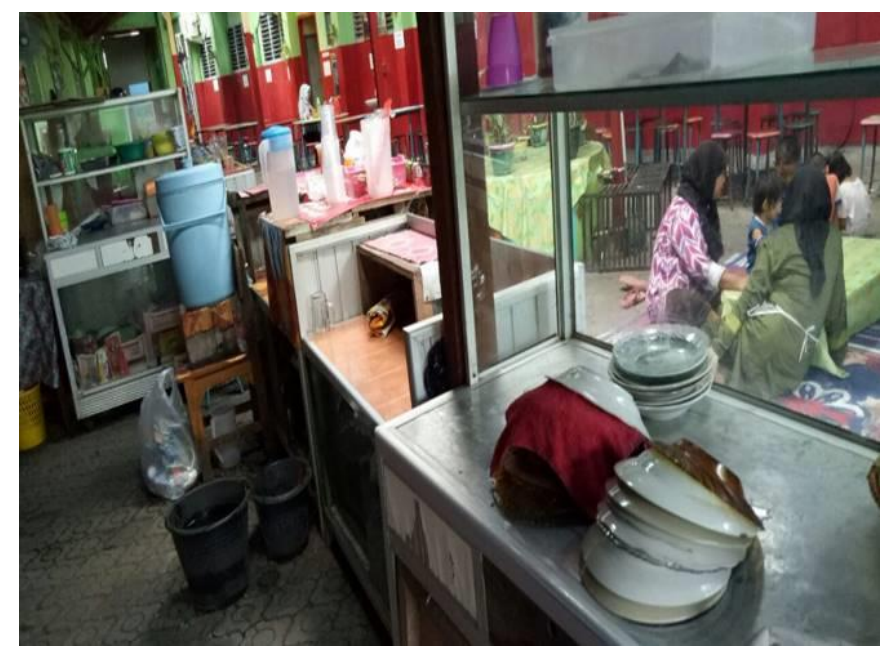

Gambar 5. Tempat penyimpanan Makanan

\section{Hasil Pemeriksaan labor}

Tabel 2. Tabel Hasil Pemeriksaan Labor

\begin{tabular}{lcc}
\hline No & Nama Pedagang & Hasil \\
\hline 1 & Kantin A & $255 \mathrm{Koloni} / \mathrm{cm} 2$ \\
& & $146 \mathrm{koloni} / \mathrm{cm} 2$ \\
& & $26 \mathrm{koloni} / \mathrm{cm} 2$ \\
& & $257 \mathrm{koloni} / \mathrm{cm} 2$ \\
2 & \multirow{4}{*}{ Kantin B } & $1012 \mathrm{koloni} / \mathrm{cm} 2$ \\
& & $0 \mathrm{koloni} / \mathrm{cm} 2$ \\
& & $0 \mathrm{koloni} / \mathrm{cm} 2$ \\
& & $0 \mathrm{koloni} / \mathrm{cm} 2$ \\
3 & \multirow{3}{*}{ Kantin C } & $0 \mathrm{koloni} / \mathrm{cm} 2$ \\
& & $0 \mathrm{koloni} / \mathrm{cm} 2$ \\
& & $21 \mathrm{koloni} / \mathrm{cm} 2$ \\
& & $8 \mathrm{koloni} / \mathrm{cm} 2$ \\
4 & Kantin D & $725 \mathrm{koloni} / \mathrm{cm} 2$ \\
& & $15 \mathrm{koloni} / \mathrm{cm} 2$ \\
& & $250 \mathrm{koloni} / \mathrm{cm} 2$ \\
& & $28 \mathrm{koloni} / \mathrm{cm} 2$ \\
& & $681 \mathrm{koloni} / \mathrm{cm} 2$ \\
& & $537 \mathrm{koloni} / \mathrm{cm} 2$ \\
& & $31 \mathrm{koloni} / \mathrm{cm} 2$ \\
& & $0 \mathrm{koloni} / \mathrm{cm} 2$ \\
\hline
\end{tabular}

Dari 20 Sampel yang diperiksa terdapat 8 sampel yang melebihi kadar maksimal dari angka kuman yang diperbolehkan pada alat makan yaitu $100 \mathrm{koloni} / \mathrm{cm} 2$, terutama pada piring kantin A yang menggunakan piring plastik sebagai alat makannya.

Tabel 3. Tabel Distribusi Angka Kuman

\begin{tabular}{cccccc}
\hline \multirow{2}{*}{ No } & Kantin & $\begin{array}{c}\text { Melebihi } \\
\text { Jumlah }\end{array}$ & $\begin{array}{c}\text { Angka Kuman } \\
\%\end{array}$ & $\begin{array}{c}\text { Diperbolehkan } \\
\text { Jumlah }\end{array}$ & $\%$ \\
\hline 1 & A & 4 & $80 \%$ & 1 & $20 \%$ \\
2 & $B$ & 0 & $0 \%$ & 5 & $100 \%$ \\
3 & C & 2 & $40 \%$ & 3 & $60 \%$ \\
4 & D & 2 & $40 \%$ & 3 & $60 \%$ \\
& Jumlah & 8 & $40 \%$ & 12 & $60 \%$ \\
\hline
\end{tabular}

\section{Pembahasan}

Angka kuman tertinggi terdapat pada piring yang digunakan oleh pedagang yang bernama $A$, dari 5 sampel yang diambel 4 sampel (80\%) terdapat angka kuman yang melebihi batas yang diperbolehkan, angka kuman yang tertinggi juga terdapat pada alat makan kantin A yaitu 1012 koloni/cm2 melebihi batas yang dperbolehkan yaitu $100 \mathrm{koloni} / \mathrm{cm} 2$. Alat makan yang digunakan adalah piring plastik, alasan pedagang karena piring plastik lebih aman untuk anak-anak, tidak mudah pecah dan ringan. Hal ini tidak lah baik, Plastik memang merupakan bahan yang ringan, elastis dan tidak mudah pecah. Piring plastik memang memiliki keunggulan, beberapa keunggulan piring plastik tersebut menjadi daya tarik para produsen makanan. Namun penggunaan piring plastik sekarang ini menjadi masalah yang serius bagi kesehatan manusia. Piring plastik dapat menimbulkan bahaya yang serius ketika :

Makanan dan Makanan yang dituangkan ke dalam piring plastik dalam keadaan panas atau air yang berada dalam piring plastik dan mendapat panas dari luar. Secara logika sederhana saja bahwa ketika Makanan panas dimasukkan ke dalam piring plastic, maka bisa dipastikan senyawa kimia di dalam plastic tersebut akan ikut larut kedalam Makanan anda, dan hal ini menyebabkan hal yang serius dan berbahaya bagi kesehatan. Hawa panas dapat menyebabkan racun thoksin dalam plastik bocor dan larut dalam air. Dan yang lebih menghebohkan adalah ternyata dari penelitian para dokter racun ini ada dalam jaringan payudara wanita sehingga menimbulkan kasus kanker payudara. Maka sebisa mungkin sebaiknya berhati-hati dan bijak dalam menggunakan piring plastik supaya tidak menimbulkan bahaya bagi kesehatan tubuh.

Pedagang kantin A hanya mencuci dengan sabun cuci piring biasa yang dijual dipasaran, untuk piring kaca biasa memang efektif namun untuk piring plastik akan sulit untuk menghilankan lemak yang kemungkinan menjadi tempat kuman dan bakteri menempel.

Untuk perlengkapan cuci piring yang menggunakan bahan dasar plastik dan melamin memang memiliki perawatan khusus. Hal ini disebabkan karena sulitnya untuk menghilangkan bau tertentu, lemak, atau minyak yang menempel pada perlengkapan cuci piring meskipun kita sudah mencucinya berulangulang, kita bisa menggunakan air perasan jeruk nipis atau sabun pencuci piring yang mengandung aroma jeruk atau lemon.

Namun ada metode sederhana yang sangat mudah dilakukan untuk mencuci peralatan yang terbuat dari bahan plastic dan juga melamin. Caranya adalah dengan merendam perlengkapan cuci piring tersebut dengan air panas selama lima belas sampai tiga puluh menit agar semua lemak atau minyak yang melekat pada perlengkapan cuci piring dapat terlepas. Setelah itu barulah cuci dengan sabun cuci piring yang mengandung aroma jeruk atau lemon, kemudian bilas dan keringkan perlengkapan cuci piring. Namun yang lebih baik adalah sebaiknya menghindari menggunakan alat makan yang dibuat dari plastik.

Bila masih ingin menggunakan alat makan plastik maka ada beberapa hal yang harus dilakukan dalam tahap mencuci alat makan, yaitu:

\section{Alternatif Pertama}

Anda perlu menyiapkan beberapa bahan, antara lain garpu, sabun cuci cair, baking soda, spons, dan lap. Caranya pun cukup mudah. Pertama, siapkan bak cuci yang sudah diisi air panas. Lalu, tuang 2 sendok makan sabun cuci cair dan baking soda ke dalam air. Bersihkan mangkok plastik Anda dari sisa-sisa makanan dengan 
menggunakan garpu. Setelah itu, rendam mangkok plastik Anda ke dalam bak cuci dan diamkan selama 30 menit.

Setelah 30 menit, gosok-gosok mangkok tersebut dengan menggunakan spons. Bilas mangkok tersebut dengan air panas dan keringkan dengan lap bersih yang sudah Anda siapkan sebelumnya.

\section{Alternatif Kedua}

Untuk alternatif yang ini, Anda hanya perlu menyiapkan cuka, lap bersih, dan sabun cuci. Caranya juga sangat praktis. Setelah Anda mengisi bak cuci Anda dengan air panas, tuangkan dua gelas cuka ke dalam bak tersebut. Masukkan alat makan yang terbuat dari plastik ke dalam bak tersebut selama 15 menit. Kemudian, angkat dan bersihkan dengan menggunakan sabun cuci piring. Bersihkan merata dan setelah dibilas, keringkan dengan menggunakan lap bersih yang sudah Anda siapkan sebelumnya. Intinya adalah jika memang susah dibersihkan dengan sabun cuci piring biasa, cobalah untuk merendam peralatan makan plastik Anda ke dalam bak yang berisi air panas (yang sudah diberi tambahan cuka atau baking soda) selama beberapa menit terlebih dahulu.

Berbanding terbalik dengan Alat Makan A, Alat makan Kantin B tidak memiliki kuman sedikitpun yaitu 0 koloni/cm2, proses pencucian piring sama dengan para pedagang kantin lainnya, namun yang membedakan adalah proses penyimpanan alat makan, pedagang ini meletakkan alat makannya dalam lemari tertutup sehingga terhindar dari kuman dan debu. Sedangkan pedagang lain meletakan alat makan yang telah dicuci di etalase toko dengan tutup seadanya memakai kain lap, bahkan ada yang tidak bertutup, prinsip mereka mencuci piring hanya untuk menghilangkan kotoran sisa makanan, tanpa mengetahui sebenarnya setelah dicuci kuman masih bisa hinggap.

\section{SIMPULAN}

1. Angka kuman pada alat makan kantin SD 47 kota jambi $40 \%$ melebihi dari angka kuman yang diperbolehkan yaitu $100 \mathrm{koloni} / \mathrm{cm} 2$

2. Pencucian telah menggunakan teknik pencucian yang dianjurkan yaitu dengan menggunakan air mengalir

3. Jenis piring, Proses pengeringan dan penyimpanan piring menjadi faktor utama adanya angka kuman pada alat makan

\section{DAFTAR PUSTAKA}

Anwar dkk,1989 Pedoman Bidang Studi Sanitai Makanan Dan Minuman Pada Institusi Penddikan Tenaga Sanitasi Pronyek Pengembangan Pendidikan Tenaga Sanitasi Pusat.Jakarta.

DEPKES (1992) Persyaratan kesehatan rumah makan dan restoran dan petunjuka pelaksanaannya. Ditjen PPM \& PL, Jakarta.

DEPKES (2000) Pedoman pengembangan perilaku hidup bersih dan sehat (PHBS) dalam pengelolaan makanan di keluarga. Ditjen PPM \& PL, Jakarta.

DEPKES (2004) Persyaratan hygiene sanitasi jasaboga. Ditjen PPM \& PL, Jakarta
Fardiaz ,S,(1997) Keamanan Makanan Tradisional dan Upaya Peningkatan Pusat antar UniversitasPangan dan Gizi, Universitas Gadjah Mada, Yogyakarta.

Hastono, S.P. (2001) Analisis data, Fakultas Kesehatan Masyarakat, Universitas Indonesia, Jakarta

Mickey, Greenland (1989) di dalam Murti, B. (1997) Prinsip dan metode riset epidemiologi, Gadjah Mada University Press, Yogyakarta.

Mukono, 2000 Prinsip Dasar Kesehatan Lingkungan .Air Langga University Press.Surabaya .

Murti, B. (1997) Prinsip dan metode riset epidemiologi, Gadjah Mada University Press, Yogyakarta.

Sastroasmoro, S. (2010) Dasar-dasar metodologi penelitian klinis, Sagung Seto, Jakarta.

Suwarni N. (2004) Hubungan kebersihan dan praktek pencucian alat makan dengan jumlah kuman pada alat makan pedagang makanan di Puja Pati Kabupaten Pati.

Slamet 1994, B 1994 Psikologi Kesehatan. Grasindo.Jakarta

Sekretariat Jenderal Jejaring Intelijen Pangan, 2005 